\title{
МАНІПУЛЮВАННЯ СВІДОМІСТЮ ЕЛЕКТОРАТУ ПІД ЧАС ВИБОРЧОГО ПРОЦЕСУ
}

Прудка Л. М.

У статті розглядається одна із багатьох проблем, яка несе загрозу для демократії на сучасному етапі розвитку України, - че використання технологій маніпулювання політичною свідомістю електорату. Технології маніпулювання політичною свідомістю електорату розвивалися разом із розвитком інституту демократії. Hamenер вони зазнали значної трансформації і відійшли від методів прямого впливу на користь методів непрямого маніпулювання. Політтехнологи постійно вдосконалюють маніпулятивні практики впливу на політичну свідомість електорату з урахуванням потенційних можливостей нових інформаційно-комунікативних технологій впливу на цільову аудиторію. У статmі наведений аналіз найбільш поширених технологій психологічного впливу на населення під час виборчого процесу. Вироблені рекомендаціі щодо ослаблення і мінімізації негативних наслідків такого процесу.

Ключові слова: маніпулювання, технології психологічного впливу, виборчий процес, електорат, масова свідомість населення.

В статье рассматривается одна из многих проблем, которая несёт угрозу для демократии на современном этапе развития Украины, - это использование технологий манипулирования политическим сознанием электората. Технологии манипулирования политическим сознанием электората развивались вместе с развитием института демократии. На данный момент они подверглись значительной трансформации и отошли от методов прямого влияния в пользу методов косвенного манипулирования. Политтехнологи постоянно совершенствуют манипулятивные практики воздействия на политическое сознание электората с учётом потенциальных возможностей новых информационно-коммуникативных технологий воздействия на целевую аудиторию. В статье приведён анализ наиболее распространённых технологий психологического воздействия на население во время избирательного процесса. Выработаны рекомендации по ослаблению и минимизации негативных последствий данного процесса.

Ключевые слова: манипулирование, технологии психологического воздействия, избирательный процесс, электорат, массовое сознание населения.

The article considers one of the many problems that poses a threat to democracy at the present stage of development of Ukraine - the use of technology to manipulate the political consciousness of the electorate. Technologies for manipulating the political consciousness of the electorate developed along with the development of the institution of democracy. At the moment, they have undergone significant transformation and moved away from direct influence methods in favor of indirect manipulation methods. Political strategists are constantly improving the manipulative practices of influencing the political consciousness of the electorate, taking into account the potential of new information and communication technologies for influencing the target audience. In modern Ukraine, manipulative processes have specific characteristics, a number of mod-

Прудка Л. М., 2019 ern phenomena are the result of the fact that manipulations by the mass political consciousness turn the free choice of citizens into a formal act, pre-programmed by the manipulator, as a result, the use of methods of manipulating political consciousness affects not only individual citizens, but also on the state as a whole. The article provides an analysis of the most common technologies of psychological impact on the population during the election process. The endless possibilities of modern media use manipulation as a way to covertly control people. And this fact is so obvious that in the scientific community it is practically not disputed. So, the psychological manipulation of the mass consciousness is not a ghost, but the phenomenon is recognized by the scientific community, it has specific controlled parameters, which makes the technical side of counteraction to this phenomenon not difficult, for the effective fight against the indicated psychological manipulations, political will and a number of systemic changes in the law are enough. The article has developed recommendations to mitigate and minimize the negative consequences of this process. In our opinion, modern Ukraine has a fairly developed state apparatus, capable of ensuring transparency and effectiveness of the political system of society, as well as the corresponding development of society. In addition, two more components are needed - a strong and stable political will, as well as appropriate legal support, which is able to comprehensively and effectively use all the means available in the arsenal of the state.

Key words: manipulations, technologies of psychological influence, election process, electorate, mass consciousness of the population.

Актуальність та постановка проблеми. Демократія визнана значущою цінністю в державно-правовому будівництві України. Однією з ознак демократії $\epsilon$ вільні вибори, тобто громадяни самі без будь-якого тиску ззовні мають приймати рішення на виборах. Однак у світлі останніх подій, які відбувалися під час президентських та парламентських виборів в Україні, серед сучасних проблем найбільш гостро виражене використання різних технологій впливу на населення.

Технології маніпулювання політичною свідомістю електорату розвивалися разом із розвитком інституту демократії. Натепер вони зазнали значної трансформації і відійшли від методів прямого впливу на користь методів непрямого маніпулювання (використання виборчих цензів, особливостей виборчих систем, формальних сторін процедури проведення виборів та ін.). Політтехнологи постійно вдосконалюють маніпулятивні практики впливу на політичну свідомість електорату з урахуванням потенційних можливостей нових інформаційно-комунікативних технологій впливу на цільову аудиторію.

У сучасній Україні маніпулятивні процеси мають специфічні характеристики, низка явищ сучасності - результат того, що маніпуляції масовою політичною свідомістю перетворюють вільний вибір громадян на формальний акт, заздалегідь запрограмований маніпулятором, як наслідок, застосування методів маніпу- 
ляції політичною свідомістю впливає не тільки на окремих громадян, але і на державу загалом.

Аналіз останніх досліджень і публікацій. Розвитку цих технологій присвячено безліч праць. Це і електоральні дослідження сучасних учених В. Полуектова, А. Горчева, Е. Богачева, А. Горбачова, які аналізують комунікативну практику політиків під час виборчих кампаній, а також дослідження класиків політичного маніпулювання У. Ліппман, П. Лазарсфела, Г. Шиллера, Д. Гербнера, Б. Багдікян і сучасних авторів Е. Дьякова, О. Пірущего, С. Володенкова, А. Коробова, Н. Урсу.

Мета статті - виявлення сутності, змісту і форм маніпулювання свідомістю електорату, визначення специфіки формування і прояву психологічних технологій маніпулювання, вироблення рекомендацій щодо ослаблення і мінімізації негативних наслідків цього процесу.

Виклад основного матеріалу. Серед арсеналу «темних» політ-технологів $\epsilon$ різні способи: неправомірні викиди бюлетенів, підкуп і залякування виборців, але, на наш погляд, правових засобів боротьби з цими явищами досить і тут частіше не вистачає політичної волі та дієвого громадянського контролю. Зазначені негативні явища «доживають свій вік», але на зміну їм приходять інші, ще більш небезпечні технології це «психологічне маніпулювання».

Науковці визначають, що маніпуляція, як особливий процес, має такі ознаки як: вплив; встановлення відносин з людиною для досягнення своїх цілей; прагнення отримати односторонню вигоду; прихований характер; використання сили; гра на слабких місцях; спонукання, привнесення мотиву; майстерність застосування [3, с. 57]. Показовим $є$ визначення маніпуляції О. Доценко: «дії, спрямовані на «приборкування до рук» іншої людини, що впроваджуються так майстерно, що у неї створюється ілюзія, що вона сама управляє своєю поведінкою» [3, с. 60].

Натепер виникають проблеми щодо осмислення психологічної сутності маніпулювання свідомістю виборця через призму законів, системи психологічного маніпулювання свідомістю за допомогою поширення чуток, форм і методів спонукання виборців до голосування, та найголовніше - це можливості і засоби боротьби з цим негативним явищем.

Завдання маніпуляторів свідомістю - приховане управління електоратом з боку «ініціатора» (представника «владного ресурсу») з метою трансформації поглядів, думок, установок і вплив у потрібному для маніпулятора напрямі. При цьому досвідчений маніпулятор задіює як свідомі, так і несвідомі складники психіки, що дає йому величезну перевагу.

У цьому контексті зазначимо, що згідно з дослідженнями, лише 6\% наших співгромадян читають і слухають передвиборні програми. Решта керуються спонтанними принципами «подобається - не подобається». Така інформація міститься в багатьох підручниках з політичної психології та політології.

Серед форм і методів психологічного маніпулювання, на наш погляд, найбільш ефективні такі як: вигідне порівняння кандидатів; «відключення розуму виборців» на емоції; підкуп виборців; голосування за «образ»; обман, хибна ідея, дача кандидатом свідомо нездійсненних обіцянок; фальсифікація [1, с. 22].

Також можна зазначити технологію впливу на свідомість людей через соціальні мережі, що вже ефективно використовується в Україні. У мережах створюється набір меседжів і мотиваторів, які схиляють віддати перевагу тому чи іншому кандидату.

$\epsilon$ вірусна технологія розміщення антирейтингу політика, коли створюються сумніви навколо кандидата шляхом публікації компромату на нього. Створюються групи, які спрямовані проти кандидатів, в яких більшість - це запрограмовані боти. Це дуже витратні, але дуже результативні технології, які можуть істотно знизити рейтинг інших кандидатів.

У 2015 році Роберт Епштейн та Рональд Робертсон, провідні наукові психологи Американського інституту поведінкових досліджень і технологій (Каліфорнія), опублікували у провідному науковому американському журналі PNAS статтю, в якій представили результати досліджень, які вони провели спільно зі своїми колегами, про те, як Google може впливати на результат виборів без нашого відома.

Google вирішує, які веб-сторінки включити в пошукову видачу і як їх ранжувати. Як це відбувається - одна 3 найбільш охоронюваних таємниць у світі [11].

Ще одна технологія - маніпулювання за допомогою адміністративного ресурсу. Адміністративний ресурс досить сильно впливає на політичну свідомість електорату, а використовувати такий механізм може лише обмежене коло суб'єктів виборчого процесу, в основному, це правлячий політичний клас. Суть цієї технології полягає в тому, щоб налаштувати державний бюрократичний апарат так, щоб у електорату з'явилися блага, раніше йому недоступні, наприклад, спрощення будь-якої формалізованої бюрократичної процедури, оголошення додаткових вихідних днів та ін. Цю технологію, як і технологію застосування економічних важелів, використовують лише тоді, коли $\epsilon$ сильний бюрократичний тиск на електорат. У такому разі під час ослаблення тиску виборець готовий легітимізувати рішення і дії правлячої політичної еліти, але часто не віддає собі звіту, що на легітимацію його змусили, отже, має місце факт маніпулювання [7, с. 51]

Елемент мовної маніпуляції. Одна з таких маніпуляцій - це «наклеювання ярликів». $€$ безліч слів-«ярликів», якими можна дискредитувати людину або ідею.

Одна з ефективних технологій - це залякування, що абсолютно не нова. Пам'ять про злочинний режим - це, звісно, добре. Але в контексті залякування громадян із метою дискредитації свого опонента вона стає звичайною цинічною технологією.

Висміювання рис опонента - також далеко не нова технологія для України. У 2004 році під час здійснення протистояння кандидатів у Президенти Ющенка та Януковича з останнього уже жартували стосовно його судимості й неосвіченості, в 2019-му під час президентських виборів ця технологія також було застосована проти кандидата в Президенти В. Зеленського.

Таким чином, вплив на свідомість виборців здійснюється за допомогою технологій психологічного маніпулювання свідомістю громадян. Безмежні можливості сучасних засобів масової інформації використовують маніпуляцію як спосіб прихованого управління людьми. І цей факт настільки очевидний, що в науковому середовищі він практично не заперечується.

Одним з опорних стовпів маніпулювання масовою свідомістю $€$ так званий «Ефект впізнавання», який використовується як у маркетингу, так і в політичних 
передвиборчих технологіях. В. Шейнов стверджує, що він грає ключову роль тому, що породжує хибне відчуття знайомства [9, с. 23].

Це стає передумовою згоди адресатів на вплив від маніпулятора - він сприймається як свій. Так, цього дуже легко домогтися за допомогою засобів масової інформації. Саме цим пояснюється боротьба, яку ведуть кандидати за телеефір у ході виборчої кампанії. При цьому і тут значну роль може зіграти «адміністративний ресурс» [7, с. 20]. Так, мали місце випадки, коли кандидат в депутати відмовлявся від теледебатів з іншими кандидатами, тим самим позбавивши ї додаткового телеефіру, але з обійманої посади щодня мав можливість бути присутнім у репортажах випусків новин на всіх каналах.

У маніпулюванні свідомістю фахівцями-психологами відкриті закони запам'ятовування, які доведені до високого рівня ефективності.

1. Закон краю. У дослідженнях німецького психолога Г. Еббінгауза підкреслюється, що повідомлення, яке перебуває на початку або наприкінці, запам'ятовується швидше, ніж відомості, що знаходяться в середині.

2. Закон незавершеної дії (або ефект Зейгарник). Такий психологічний закон говорить, що незавершена дія запам'ятовується міцніше, пам'ятається довше закінченого в середньому на 50\%. Навпаки, завершеність дії сприяє забуванню. Цим пояснюється запам'ятовування і активна дія газетних заголовків, за цим принципом діють «нарізки» новинних стрічок в Інтернеті і на перших шпальтах друкованих видань, нескінченні анонси новин по телебаченню [6].

3. Закон емоцій. Безумовно, чим більше емоцій викликає інформація, тим краще вона запам'ятовується. Емоції пожвавлюються асоціаціями, новими образами і повідомленнями, які їх «будять». При цьому для маніпулятора навіть неважливо, як поставилася людина до повідомлення, яке вона запам'ятає мимоволі.

Люди, як правило, «голосують серцем», особливо це стосується жінок. Тому однією з головних мішеней маніпуляторів $\epsilon$ сфера людських емоцій. Один з авторів доктрини виборчої кампанії Р. Ніксона в 1968 році У. Гевін писав: «Розум вимагає надзвичайно дисципліни, концентрації уваги. Багато легше звичайне враження. Розум відштовхує глядача, логіка докучає йому. Емоції збуджують, вони ближче до поверхні, м'якше куються». Управління свідомістю людини базується на тих емоційних передумовах, які в цій свідомості вже $\epsilon$, - страх, любов, жага чогось. Не потрібно ні в чому переконувати, досить задіяти наявний емоційний потенціал, взяти в руки управління «емоційним вибухом». Для того щоб «зіграти» на емоціях, не потрібні стрункі логічні викладки. Іноді буває досить переконливого тону і чесної особи маніпулятора, щоб повірити в заявлену їм «очевидність» $\mathrm{i}$ «безальтернативність» його суджень [2, с. 127].

4. Закон посилення першого враження. Чим сильніше перше враження, тим яскравіший образ; чим більше джерел (телеканалів, інтернет-ресурсів), якими передається певна інформація, тим запам'ятовування міцніше.

5. Закон інтересу. Інформація, що викликає інтерес або цікавість, запам'ятовується легко. Навмисне поширення чуток під час виборчої кампанії мають певний потенціал впливу на електорат.
Взагалі в системі психологічного маніпулювання свідомістю мас одним з найпотужніших знарядь $\epsilon$ чутки. Політтехнологами навіть вироблена низка вимог, які підвищують їх ефективність. Вони мають бути значущими для об'єкта впливу (тобто зачіпати актуальні інтереси соціальної групи або суспільства загалом); бути зрозумілими для виборця; бути добре підготовленими і перебувати під контролем.

У впливі на виборця широко використовуються різні форми і методи спонукання до «правильного» голосування. Тут найбільш типовим $€$ шлях, коли засоби масової інформації створюють образ «обранця народу». При цьому вони вирішують такі завдання: «роблять» кандидата відомим, тобто публічним політиком; формують позитивний імідж (образ) кандидата в очах виборців, роблячи його більш привабливим, ніж у конкурентів. При цьому, як правило, реальні справи, позиції підміняються враженнями; свідомі, раціональні компоненти - емоціями і впливом на інтуїцію.

Ще цікавіше і ефективніше в цьому сенсі виглядає загальнодоступна інформація про технічне дозування і надання інформації. Так, С. Кара-Мурза вказує, що виявлений «тимчасовий обсяг пам'яті»: цілісне повідомлення має укладатися в проміжок від 4 до 10 секунд, а окремі частинки повідомлення - в проміжки від 0,1 до 0,5 секунди [4, с. 423]. Тобто правильно побудоване повідомлення буде засвоєне незалежно від згоди з ним і буде діяти не тільки через свідомість, але навіть більшою мірою через підсвідомість людини.

$\epsilon$ i iнші технічні засоби впливу на свідомість людини, наявність яких визнає не лише наукова громадськість, але і держава в особі законодавця. Так, у п. 1 ст. 8 «Загальні вимоги до реклами» Закону України «Про рекламу» прямо говориться: «У рекламі забороняється:... використовувати засоби і технології, які діють на підсвідомість споживачів реклами», але контроль за цим відбувається тільки формально i, на жаль, ця норма $\epsilon$ складно доказовою щодо шкідливості й ефективності технічних прийомів подачі (надання) відомостей через засоби масової інформації.

Висновки. Так, психологічна маніпуляція масовою свідомістю - це не привид, а явище, визнане науковою громадськістю, воно має конкретні контрольовані параметри, що робить технічну сторону протидії цьому явищу нескладною, для ефективної боротьби із зазначеними психологічними маніпуляціями досить політичної волі і низки системних змін права.

Для цього необхідно провести цільові психологічні дослідження з метою виявлення психологічних засобів маніпуляції і створити механізм з нормативного закріплення й оновлення їх переліку (можливо, за аналогією з переліком наркотичних засобів, психотропних речовин та їх прекурсорів, що підлягають контролю в Україні). До того ж потрібні зміни в законодавстві щодо формування системи санкцій за правопорушення у цій сфері.

На наш погляд, сучасна Україна має досить розвинений державний апарат, здатний забезпечити прозорість i ефективність політичної системи суспільства, а так само відповідний розвиток суспільства. Крім цього, необхідні ще два складники - сильна і стабільна політична воля, а також відповідне правове забезпечення, яке здатне комплексно й ефективно використовувати всі засоби, наявні в арсеналі держави. 


\section{Проблеми становлення правової демократичної держави}

\section{Література}

1. Горбачёв А.А. Особенности манипулятивных технологий в политике (на примере нарушения законов логики) Людина. Світ. Суспільство. (до 175-річчя філософського факультету. Дні науки філософского факультету. 2009. Міжнар. наук. конф. (21-22 квітня 2009 р.) : матеріали доповідей та виступів. Київ : Видавничо-поліграфічнийцентр «Київський університет», 2009. Ч. 8. C. $22-24$.

2. Доктрина Нільсона / під ред. Ю.П. Давидова, В.В. Журкіна, В.С. Руднева. Москва : Наука, 1972, 232 с.

3. Доценко Е.Л. Психология манипуляции: феномен, механизмы и зашита. Москва, 1997. 344 с.

4. Кара-Мурза С. Г. Манипуляция сознанием. Москва, 2005. 832 C.

5. Картер Р. Как работает мозг. Москва, 2014. 224 с.

6. Назаренко Е. Эффект Зейгарник: мысли, мешающие медитировать. Психологический портал тренингового ценmpa "Live-and-learn". URL: https://www.live-and-learn.ru/ catalog/article/effekt-zeygarnik-mysli-meshayushchiemeditirovat/ (дата звернення: 28.11.2019).
7. Парамонов Д., Кириченко В. Административный ресурс в избирательных кампаниях : научная монография. Ростов-на-Дону, 2003. 80 с.

8. Почепцов Г. Політична реклама України: стратегії виграшу чи програшу. Вісник Київського ун-ту ім. Т.Г. Шевченка. Сер. «Журналістика». Київ, 1997. Вип. 5. С. 34-36.

9. Шейнов В.П. Манипулирование сознанием. Минск : Харвест, 2010. 768 с.

10. Шейнов В.П. Психологическое влияние. Минск : Харвест, 2007. 638 с.

11. Robert Epstein and Ronald E. Robertson The search engine manipulation effect (SEME) and its possible impact on the outcomes of elections, 2015. URL: https: / / www. pnas.org/content/pnas/112/33/E4512.full. pdf?with-ds=yes (дата звернення: 10.12.2019).

Прудка Л. М., кандидат психологічних наук, доцент кафедри криміналістики та психології одеського державного університету внутрішніх справ 